\title{
Permeable Concrete Block Paving Applications in the United Arab Emirates
}

\author{
James Eyre $^{\# 1}$, Prakash Bhalchandra ${ }^{* 2}$ \\ ${ }^{\#}$ Civil Engineer, Mott MacDonald Ltd \\ Level 2 Festival Tower, Festival City, Dubai, UAE
}

\begin{abstract}
Permeable Concrete Block Paving (CBP) solutions are well established and widely implemented throughout the USA and Europe, although only recently applied in the Middle East and Asia. The concept of permeable CBP originated in Germany in the early 1980's and has seen rapidly increasing acceptance by engineers and landscapers globally (see [1] for further details). Permeable CBP is a Construction Industry Research and Information Association (CIRIA) recognised source control component of Sustainable Drainage Systems (SuDS). An increased focus on SuDS for urban drainage schemes initiated from their identification as a promising 'means of implementation' of the United Nations Agenda 21 action plan on Sustainable Development (1992), [2] and in response to subsequent global trends following the introduction in the USA of regulations requiring the control of run-off for major projects.
\end{abstract}

This paper investigates the application of permeable CBP to SuDS schemes in the United Arab Emirates (UAE) and in detail, the world's largest and first application in the Middle East of the Hanson Formpave ${ }^{\circledR}$, Aquaflow system, covering an area of $196,200 \mathrm{~m}^{2}$ in Dubai (referred to throughout this paper as 'the project'). Considering a pre-constructed, 'eco-signature' developed golf-course, a sustainable scheme incorporating a residential roads solution offering dual use of space and no additional land take was highly beneficial, ultimately leading to the selection of the Formpave ${ }^{\circledR}$ Aquaflow system by the client. The result is a significant reduction in the environmental and economic impacts of an alternative, dedicated surface-water drainage network with its associated requirements for multistage pumping stations across a highly contoured site.

Key areas of this study include structural and hydrological design criteria and the selection of an infiltration system over a combined, conventional paving and storm-water drainage design concept. Further evaluation of the systems long-term infiltration/ water permeability performance considers regional design adaptation, including the effects of entrainment of mineral and organic fines, construction detailing, sequencing and installation methodologies on service life of the completed road network.

Keywords - Permeable, Aquaflow, infiltration, run-off, entrainment.

\section{INTRODUCTION}

Because significant precipitation is rare in the Gulf region, "some amount of street flooding is typically allowable". In Dubai, United Arab Emirates (UAE), "the design criterion for the drainage system is based on the time required to clear flooding for a designated rainfall event'" (see [6]). The current criterion is an $18 \mathrm{~mm}$ storm and a maximum clear time of six hours for residential areas, see [3]. Sustainable Drainage Systems (SuDS) provide a cost effective sequence of management practices which reduce pollution principally of local water bodies, reduce susceptibility to flooding and enhance amenity, widely favoured by developers in the UAE. Permeable and porous pavement systems are increasingly used as a source control component of such schemes. Permeable CBP allows storm water run-off to penetrate between paving joints of the surface course into a filter stone reservoir, through fabric geotextile layers. Such designs may rely solely on ground infiltration where permeability of the soils in the underlying area permits (project conditions of 2.0 x $10^{-6}$ to $7.5 \times 10^{-6} \mathrm{~m} / \mathrm{sec}$ are rated by the Dubai Municipality [3] as borderline "good/poor drainage"'). Alternatively subbase courses may be utilised to attenuate run-off for partial infiltration and/or for underdrain discharge to sewers/ retention ponds, where underlying soil permeability is insufficient.

Commonly termed "Grey" infrastructure approaches, incorporating "engineered" components are often necessary for the implementation of SuDS solutions in the UAE, see [4]. Drainage applications in the region are required to store, attenuate and convey water over considerable distances if account of the quality and quantity of surface run-off and the amenity and aesthetic value of surface water is to be taken, in frequently dis-located areas of the urban environment.

\section{SUDS CONCEPT DESIGN DEVELOPMENT}

The determining factor for the surface water drainage system used for the project was the need to avoid costly and environmentally undesirable piped drainage. Associated requirements of a piped drainage system are multi-stage pumping stations and discharge into large storage areas for rainwater harvesting, irrigation or ground infiltration. Natural ground infiltration is preferred where possible with smaller, relatively closely spaced soakaway/ storage facilities to accommodate storm water.

The preliminary, piped network design incorporated seventeen pumping stations sited at various 'low points' in the estates and at 'low points' around the perimeter ring road. In some cases pumping stations were designated to lift water to a nearby surface water gravity system that falls to a further downstream pumping station. In other situations, pumping was required over a considerable distance to a localised 'high 
point', with falls by gravity to a subsequent in-line pumping station. The cost of the surface water drainage outlined was competitively tendered and quoted initially at over 85 million AED, approaching double the budget estimated costs.

Eliminating the extensive infrastructure outlined above, the final development includes a conventional asphalt ring-road, constructed with a crossfall of $2 \%$ and flush kerb at the outer channel. Drainage is managed by run-off over the flush kerb to landscape areas where infiltration will occur. Critically, golf-course conflict for facilities required at the location of low areas for discharge of run-off is avoided. Ring-road collection measures include swales, created by contouring the landscape areas, french drains and soakaways in different forms.

Filter stone below permeable cart paths forms the primary soakaway components of the ring-road drainage solution, whilst the internal residential roads are constructed of permeable CBP and provide a water filtration, retention and detention facility (Interpave 'System A', as in [5]). The above solution overcame the constraints of competition for space with existing golf-course lakes, landscaping and within the remaining, narrow utilities corridors available parallel to the community roads. To accommodate variable topography gradients and provide adequate storage capacity for residential roads and courtyards, additional surface water storage is provided within the cross-section of the roads. Infiltration trenches at a depth of $1.6 \mathrm{~m}$ from Finished Road Level (FRL), width of $2 \mathrm{~m}$ and lengths of between $2.0 \mathrm{~m}$ and $3.5 \mathrm{~m}$, are provided at Full Height Restraints (FHR's) in the pavement construction. FHR's are typically located at speed humps positioned ahead of junctions and otherwise, independently at approximately $150 \mathrm{~m}$ spacing. By compaction of subgrade for road formation, the percolation value for the underlying soil (ranging site-wide from 1.3 to $13.5 \mathrm{sec} / \mathrm{mm}$ for the project) is further diminished. For storage capacity design infiltration was therefore ignored. A geo-grid inclusion (notably for the heavier load category design requirements of the clubhouse access road) enhances aggregate interlocking, promoting an increase in load-spread through aggregate transfer and providing improvements in structural performance.

\section{A. Conventional System Variables}

Drainage calculation and design in Dubai, typically uses run-off calculated in a MOdel for Urban SEwers (MOUSE) program using "Hydrologic Model A, configured to mimic the rational method', The Dubai regional drainage facilities are divided into numerous, 'hydraulically independent, individual subsystems terminating at a pumping station or freely discharging into the Dubai Creek or Arabian Gulf' (see [6]). The 'Dubai Municipality Sewerage and Drainage Design Criteria' for local drainage facilities, specifies a design storm of $30 \mathrm{~mm}$ in 90 minutes representing a return period of 5 years (see [3]).

Modelling of a piped system can be undertaken accurately, whilst flow rates through sub-base courses accounting for friction over variable aggregate grading's and variable compaction conditions is difficult to accurately determine for permeable pavement systems. Long-term monitoring programmes cited in [7], CIRIA Report C582 (2002), suggest that the peak rate of run-off from conventional concrete block pavements is reduced by $23 \%$ to $98 \%$, with between 3 and $17 \mathrm{~mm}$ of rainfall required before sub-base discharge is observed. A design for permeable CBP schemes is therefore conservatively required beyond specified requirements, commonly to 1 in 30 year events in the UAE and in the United Kingdom to 100 year return periods, considering a run-off coefficient of $90 \%$ to $100 \%$ in most cases.

A further implication to consider in the design of permeable CBP is the underlying soil bearing capacity and associated compaction requirements. In the case of heavy duty loadings, conventional $\mathrm{CBP}$ and flexible pavement constructions offer established performance, whilst permeable CBP and similarly flexible pavements with a porous asphalt wearing course will require structural enhancement over the sub-base layers. A road-base course of Hot Rolled Asphalt (HRA), Dense Bituminous Macadam (DBM) or High Density Macadam (HDM) is conventionally applied with a Porous Asphalt wearing course. Similar inclusions of hydraulically bound, coarse-graded aggregate layers in permeable CBP design will facilitate increased load capacity (Interpave load categories 3 to 6 , see [5]). Provided a minimum thickness of $125 \mathrm{~mm}$ of hydraulically bound aggregate is provided, DBM with appropriate perforations to maintain water attenuation may also be used to substitute the remaining thickness of aggregate required. $75 \mathrm{~mm}$ diameter perforations on a $750 \mathrm{~mm}$ orthogonal grid are the specified requirements for conversion of an impermeable to permeable DBM layer.

Heavy duty loading and higher road speeds for the ringroad and clubhouse access roads of the project constrained the application of CBP for such areas, particularly where sabkha materials have been encountered in road foundations. The presence of sabkha material limits ground infiltration (permeability circa. $1 \times 10^{-8} \mathrm{~m} / \mathrm{sec}$ ) and prior to selection of the solutions outlined previously in this section, forced consideration of a permeable CBP attenuation and discharge system design. A permeable DBM layer with sub-base aggregate storage for subsequent transfer to sewers or for irrigation was proposed in sabkha locations. An infiltration basin adjacent to pre-constructed golf course irrigation lakes and additionally direct discharge into the lakes was also evaluated. Requirements for purpose built basins, emergency spillways and sand/silt removers on line, however eliminated this option from further design development.

\section{B. Cost Benefit Analysis \& Whole Life Costs}

Whole Life Costs are a key consideration for a developer in the analysis and selection of flexible vs. rigid, and permeable vs. impermeable pavement solutions. A comparative study (Interpave (2006), [8]) of Pavement Quality Concrete (Rigid Construction), Asphalt (Flexible construction) and permeable CBP designs was carried out for Estate road applications 
within UK housing developments. Permeable CBP with an attenuation and discharge to outfall drainage design (equivalent to conventional solutions) provides the lowest Whole Life Cost (WLC) of all options considered. Permeable CBP (full infiltration design) was evaluated against all other options in terms of initial cost, providing the most cost effective solution for subgrade California Bearing Ratio (CBR) values of $10 \%$ and above. Table I illustrates the direct, initial cost comparison of a conventional CBP solution with the selected permeable CBP solution for the project.

TABLE I

CONVENTIONAL IMPERMEABLE PAVEMENT VS. PERMEABLE CONCRETE BLOCK PAVING SOLUTIONS

\begin{tabular}{|c|c|c|c|c|}
\hline \multicolumn{5}{|c|}{$\begin{array}{l}\text { Cost comparison for conventional impermeable pavement with } \\
\text { surface water drainage system vs. permeable CBP options }\end{array}$} \\
\hline \multirow[t]{2}{*}{ Item } & \multirow[t]{2}{*}{ Description } & $\begin{array}{l}\text { Modified } \\
\text { initial design } \\
\text { option }\end{array}$ & $\begin{array}{l}\text { Implemented } \\
\text { option }\end{array}$ & \multirow[t]{2}{*}{ Remarks } \\
\hline & & $\begin{array}{c}\text { CBP with } \\
\text { piped surface } \\
\text { water } \\
\text { drainage } \\
\text { system, } \\
\text { including } \\
\text { pump } \\
\text { stations }\end{array}$ & $\begin{array}{c}\text { Permeable } \\
\text { CBP } \\
\text { (Full } \\
\text { infiltration) }\end{array}$ & \\
\hline 1 & $\begin{array}{l}\text { Supply \& } \\
\text { Installation } \\
\text { cost of piped } \\
\text { drainage } \\
\text { system and } \\
\text { outfalls }\end{array}$ & $52,638,046.27$ & & \\
\hline 2 & $\begin{array}{l}\text { Earthworks } \\
\text { for road } \\
\text { formation }\end{array}$ & $1,909,000.00$ & $1,909,000.00$ & $\begin{array}{l}\text { Required for } \\
\text { both options }\end{array}$ \\
\hline 3 & $\begin{array}{l}\text { Supply and } \\
\text { installation } \\
\text { cost for } \\
100 \mathrm{~mm} \text { road- } \\
\text { base and } \\
250 \mathrm{~mm} \text { sub- } \\
\text { base courses, } \\
\text { flush and } \\
\text { upstand kerbs }\end{array}$ & $21,867,004.00$ & $21,867,004.00$ & $\begin{array}{l}\text { Required for } \\
\text { both options. } \\
\text { (Conservative } \\
\text { estimate for } \\
\text { conventional } \\
\text { block paving } \\
\text { construction) }\end{array}$ \\
\hline 4 & $\begin{array}{l}\text { Supply and } \\
\text { installation } \\
\text { cost of laying } \\
\text { course and } \\
\text { surface } \\
\text { paving }\end{array}$ & $10,787,933.80$ & $30,677,696.62$ & $\begin{array}{l}\text { Permeable } \\
\text { and } \\
\text { impermeable } \\
\text { geotextile, } \\
\text { laying course } \\
\text { and surface } \\
\text { paving } \\
\text { blocks. }\end{array}$ \\
\hline & $\begin{array}{l}\text { TOTAL } \\
\text { (AED) }\end{array}$ & 87,201,984.07 & $54,453,700.62$ & \\
\hline & $\begin{array}{l}\text { Saving } \\
(\mathrm{AED})\end{array}$ & & $32,748,283.45$ & \\
\hline
\end{tabular}

A hydraulically bound, coarse-graded aggregate road base is required for all permeable $\mathrm{CBP}$ designs receiving intermittent $\mathrm{HGV}$ loading ( 0.015 to $15 \mathrm{msa})$. Conventional CBP design would often not require a separated road base and sub base gradation to be considered (BS 7533-2:2001 Cat
IIIb), until more frequently sustained $\mathrm{HGV}$ traffic was anticipated (BS 7533-2:2001 Cat II). Up to 350mm of coarsegraded aggregate sub base may be utilised in a single layer for permeable CBP subject to loading categories of $0-100$ sa. $80 \mathrm{~mm}$ pavers with a $50 \mathrm{~mm}$ laying course are typically required for all permeable CBP applications for estate roads. $50 \mathrm{~mm}$ provides an optimal thickness for reliably consistent compaction of the coarse, angular or sub-angular material required. A reduced paver and accompanying laying course thickness is generally required in conventional CBP applications (50-60mm pavers and 30mm laying course).

With further reference to the Interpave (2006) 'Comparative Initial Construction and Whole Life Cost Analyses for Pavements' report, for subgrade of a CBR less than $10 \%$, a full infiltration, permeable CBP design was not a considered option. With significantly reduced regular maintenance requirements however, the maintenance strategies for a full infiltration solution will allow for a further reduction in WLC, over a piped drainage network. Fig. 1 illustrates the findings of the Interpave (2006) report.

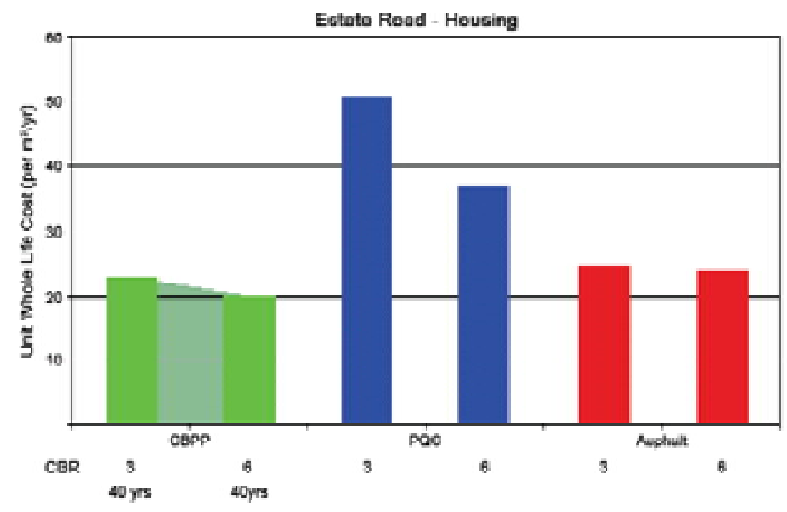

Fig. 1 Whole Life Costs - Concrete Block Permeable Pavements (CBPP), Pavement Quality Concrete (PQC) \& Asphalt (Source: Interpave 2006 Uniclass L534:L217)

Considering a 40 year service life in the above analyses, the expected longevity of 20 and 40 years for flexible and rigid pavement construction respectively, is a significant factor. Permeable CBP performing consistently with flexible pavement constructions (a conservative assumption), will reach an intervention level where cost expenditure is required to maintain the design performance of the road asset. Shahin and James (1994) [9], outlines the necessity for timely rehabilitation intervention, concluding that a delay of $12 \%$ of the life of the pavement can result in up to a $40 \%$ reduction in road conditions and an associated "factor of four increase in maintenance costs', Fig. 2 provides an estimate of annual maintenance costs for the project, notably considering a 1 in 25 year intervention for substantial rehabilitation works. Overhead costing is excluded from this analysis. 


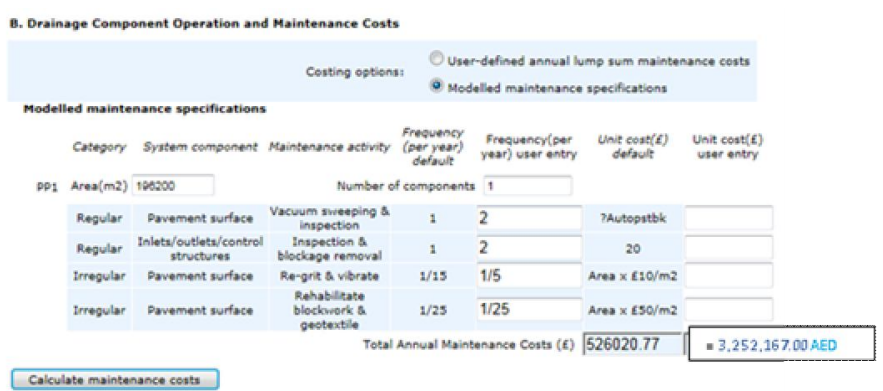

Fig. 2 UK Sustainable Drainage Guidance and Tools (Source: HR Wallingford - http://www.uksuds.com/costintro.aspx)

The quantifiable benefits of Cost Benefit Analyses (CBA') are largely the same for impermeable and permeable solutions, provided appropriately designed in both cases. A WLC approach is arguably therefore a more favourable comparison mechanism for permeable and impermeable solutions. A CBA is more appropriately utilised for the evaluation of Surface Water Management Plans (SWMPs) or similar approaches, to assess the value of benefits from their implementation, primarily in terms of reduced flooding and associated reduction of pollutant loads to watercourses. Many of the important, non-monetised benefits of a permeable solution over an impermeable alternative are not easily accounted for in a detailed CBA and are further detailed in Table II of this paper.

Performance and whole life costs of best management practices and SuDS were evaluated by UKWIR (2005), [10], concluding that for a given size of facility, "a high level of maintenance increased the whole life cost by two or three times compared with the same facility with a lower level of maintenance'. The levels of maintenance required for each system will have the most significant effects on their Net Present Value (NPV), as clearly reflected in section 3.2 of Table II of this paper. 
TABLE II

CONVENTIONAL IMPERMEABLE PAVEMENT VS. PERMEABLE CONCRETE BLOCK PAVING SOLUTIONS

\begin{tabular}{|c|c|c|c|}
\hline $\begin{array}{l}\text { Sr } \\
\text { No. }\end{array}$ & Aspect & Conventional - impermeable construction & Permeable Concrete Block Paving construction \\
\hline 1 & Construction Methodology & & \\
\hline 1.1 & Cross-section composition & $\begin{array}{l}\text { Conventional CBP typically consists of a } \\
\text { subgrade with one or two overlying courses of } \\
\text { compacted pavement material and a surface } \\
\text { seal. } \\
\text { Utilises the surface seal to prevent entry of } \\
\text { water into the system, accordingly protecting } \\
\text { the base-course, sub-base and subgrade } \\
\text { integrity. } \\
\text { Common surfacing materials are asphalt, } \\
\text { concrete and concrete/clay block paving. }\end{array}$ & $\begin{array}{l}\text { Crushed gravel, rock or concrete possessing well } \\
\text { defined edges. Sound, clean, non-friable and free } \\
\text { from clay or other deleterious matter. The material } \\
\text { must be non-plastic when tested in accordance } \\
\text { with BS } 1377 \text { Test No. } 4 \text {. Laying course and sub- } \\
\text { base must have a minimum } 10 \% \text { fines value of } \\
\text { 150KN (BS } 812 \text { Part 111). } \\
\text { Manufacturers will commonly specify their own } \\
\text { cross section aggregate grading's, requiring } \\
\text { specialist suppliers. Open graded materials are } \\
\text { however specified and available for conventional } \\
\text { highways construction, e.g. Type } 3 \text { sub-base from } \\
\text { the Highways Agency Specification for Highway } \\
\text { Works } \\
\text { (Highways Agency 2004, [11]). }\end{array}$ \\
\hline 1.2 & Paving joint treatment & Conventional jointing sand. & $\begin{array}{l}\text { Joint material will be a crushed rock that is fine } \\
\text { gravel sized (Borgwardt (2006), [12] - suggesting } \\
\text { an optimal } 2 / 5 \mathrm{~mm} \text { crushed gravel). Conventional } \\
\text { jointing sand is not suitable as a medium for } \\
\text { surface water to pass down through the pavement. }\end{array}$ \\
\hline 1.3 & $\begin{array}{l}\text { Subgrade treatment } \\
\quad(\text { CBR }<5 \%)\end{array}$ & $\begin{array}{l}\text { Impermeable layering may be tailored to highly } \\
\text { differential strength classes, to accommodate } \\
\text { highly variable subgrade conditions. }\end{array}$ & $\begin{array}{l}\text { Subgrades of CBR }<5 \% \text { are often too fine to } \\
\text { permit infiltration design options. } \\
\text { Permeability requirements limit the application of } \\
\text { permeable CBP over certain subgrade conditions, } \\
\text { requiring a substantial increase in coarse-graded } \\
\text { aggregate layers or a capping layer over subgrade } \\
\text { strata (typically <5\% CBR). The presence of a } \\
\text { capping layer however limits infiltration options, } \\
\text { additionally requiring a protective, impermeable } \\
\text { membrane and consequently an alternative } \\
\text { discharge solution for coarse-graded aggregate } \\
\text { sub-base and stored surface water. }\end{array}$ \\
\hline
\end{tabular}




\begin{tabular}{|c|c|c|c|}
\hline $\begin{array}{c}\text { Sr } \\
\text { No. }\end{array}$ & Aspect & Conventional - impermeable construction & Permeable Concrete Block Paving construction \\
\hline 2 & Drainage & & \\
\hline 2.1 & Modelling & $\begin{array}{l}\text { MOUSE - MOdel for Urban SEwers. } \\
\text { Sophisticated simulation of real-time controls, } \\
\text { evaluating Rainfall Development } \\
\text { Inflow/Infiltration (RDII - Hydraulic Model A } \\
\text { in Dubai) network capacity and for predicting } \\
\text { local flooding based on continuous modelling } \\
\text { of the rainfall process. The program may also } \\
\text { be used for estimating sediment build-up and } \\
\text { transport, optimization and analysis of water } \\
\text { quality and sediment problems, based on } \\
\text { steady and unsteady flows in pipe and channel } \\
\text { networks (see [6] for further details). }\end{array}$ & $\begin{array}{l}\text { Permeable surfaces provide an attenuation } \\
\text { function, slowing the rate and volume of water } \\
\text { entering drainage systems where full infiltration is } \\
\text { not achievable. Evaporation of water absorbed into } \\
\text { paving and sub-surface materials, initial runoff } \\
\text { losses and runoff routing provides further } \\
\text { modelling complications. } \\
\text { The rate of infiltration can be determined using the } \\
\text { approach described in CIRIA Report } 156 \text { (CIRIA, } \\
\text { 1996, [13]). }\end{array}$ \\
\hline 2.2 & Drainage Components: & & \\
\hline 2.2 .1 & Gullies & $\begin{array}{c}\text { Gully Inlets commonly located at all low points } \\
\text { and at asphalting intervals to avoid overflowing } \\
\text { of gutters. Maximum spacing between gullies } \\
\text { is typically } 25 \mathrm{~m} \text {. } \\
\text { Alternative channel drainage at pavement } \\
\text { perimeters. }\end{array}$ & Not required \\
\hline 2.2 .2 & Sewer and lateral sewer & $\begin{array}{l}\text { A typical minimum size of sewer is } 250 \mathrm{~mm} \\
\text { diameter. }\end{array}$ & $\begin{array}{c}\text { 3No. distinct design types: } \\
\text { Infiltration only (Interpave System A) - } \\
\text { Not required. } \\
\text { Attenuation and discharge to outfall (Interpave } \\
\text { System B \& C) - Under-drain sewer required to } \\
\text { discharge. Lateral sewers not required. }\end{array}$ \\
\hline 2.2 .3 & Pumping Stations & $\begin{array}{l}\text { Required for piped water distribution and/or } \\
\text { discharge to outfall, where not achievable via a } \\
\text { gravity network. }\end{array}$ & $\begin{array}{c}\text { 3No. distinct design types: } \\
\text { Infiltration only (Interpave System A) - } \\
\text { Not required. } \\
\text { Attenuation and discharge to outfall (Interpave } \\
\text { System B \& C) - Required for piped under-drain } \\
\text { water distribution and/or discharge to outfall } \\
\text { where not achievable via a gravity network. }\end{array}$ \\
\hline 2.2 .4 & Soakaways & $\begin{array}{l}\text { Typical details: } \\
\text { Infiltration trenches, offset and parallel with } \\
\text { road carriageways are commonly provided as a } \\
\text { French drain configuration, to convey run-off } \\
\text { volumes to upstream storage/ discharge } \\
\text { locations. }\end{array}$ & $\begin{array}{l}\text { 3No. distinct design types: } \\
\text { Infiltration only (Interpave System A) - May be } \\
\text { fully contained under the road carriageway } \\
\text { Attenuation and discharge to outfall (Interpave } \\
\text { System B \& C) - Required under-drain network } \\
\text { may be routed under the road carriageway to } \\
\text { upstream storage/ discharge locations. }\end{array}$ \\
\hline 2.2 .5 & $\begin{array}{l}\text { Outfalls/ Discharge to } \\
\text { watercourse }\end{array}$ & $\begin{array}{l}\text { Required for piped water distribution network. } \\
\text { Detention pond storage volume is to be based } \\
\text { on } 100 \mathrm{~mm} \text { of run-off ( } 50 \text { year return period). } \\
\text { Alternatively rain garden, soakaway, combined } \\
\text { sewers or separate surface water sewer systems } \\
\text { are required. }\end{array}$ & $\begin{array}{c}\text { 3No. distinct design types: } \\
\text { Infiltration only (Interpave System A) - } \\
\text { Not required. } \\
\text { Attenuation and discharge to outfall (Interpave } \\
\text { System B \& C) - Required. }\end{array}$ \\
\hline
\end{tabular}




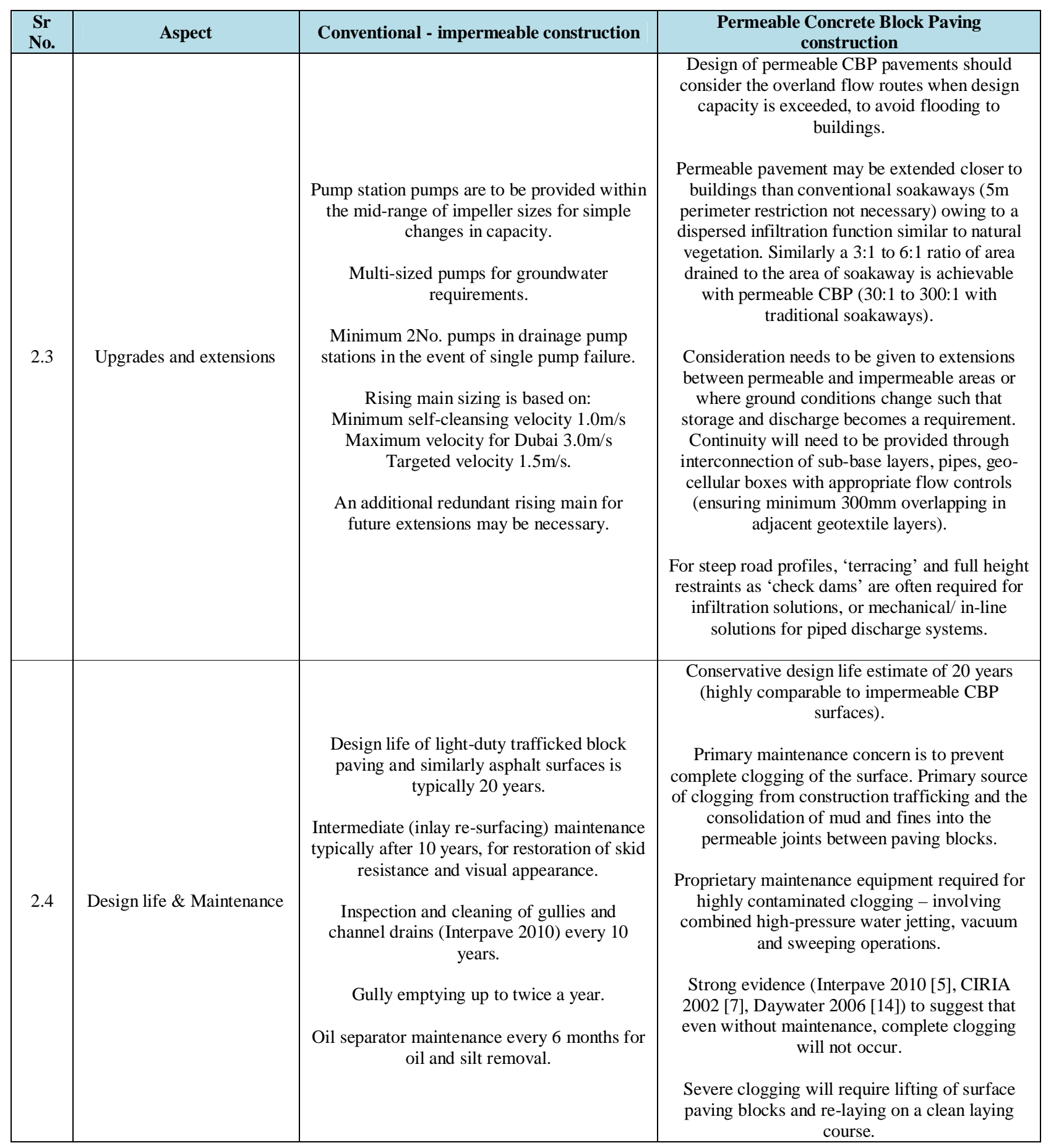


International Journal of Engineering Trends and Technology (IJETT) - Volume 16 Number 5 - Oct 2014

\begin{tabular}{|c|c|c|c|}
\hline $\begin{array}{l}\text { Sr } \\
\text { No. }\end{array}$ & Aspect & Conventional - impermeable construction & Permeable Concrete Block Paving construction \\
\hline 3 & Cost & & \\
\hline 3.1 & Initial Cost - Construction & $\begin{array}{l}\text { Project Estimate: } \\
87,200,000 \mathrm{AED}=444 \mathrm{AED} / \mathrm{m}^{2}\end{array}$ & $\begin{array}{l}\text { Project Estimate: } \\
54,450,000 \mathrm{AED}=278 \mathrm{AED} / \mathrm{m}^{2}\end{array}$ \\
\hline $3.2 \mathrm{a}$ & $\begin{array}{l}\text { Whole-life cost estimate } \\
\text { (incl. Operation \& } \\
\text { Maintenance, based on UK } \\
\text { Interpave L534: L217) }\end{array}$ & $\begin{array}{l}288 \mathrm{AED} / \mathrm{m}^{3} / \text { year WLC (based on the ratio of } \\
\text { initial cost to WLC proposed by Interpave } \\
\text { L534:L217) }\end{array}$ & $\begin{array}{l}241 \mathrm{AED} / \mathrm{m}^{3} / \text { year WLC (based on the ratio of initial } \\
\text { cost to WLC proposed by Interpave L534:L217) }\end{array}$ \\
\hline $3.2 b$ & $\begin{array}{l}\text { Whole-life cost comparison } \\
\text { (UK, Interpave estimate) }\end{array}$ & $\begin{array}{l}\text { CBR 6\% Estate Roads - Housing: A } \\
\text { conventional CBP or equivalent Pavement } \\
\text { Quality Concrete system with piped drainage } \\
\text { network carries an approx. Whole Life Cost } \\
\text { (WLC) of: } \\
229 \text { AED per } \mathrm{m}^{3} / \text { year over a } 40 \text { year life. }\end{array}$ & $\begin{array}{l}\text { CBR 6\% Estate Roads - Housing: A Permeable } \\
\text { CBP system with piped drainage network carries an } \\
\text { approx. Whole Life Cost (WLC) of: } \\
124 \text { AED per } \mathrm{m}^{3} / \text { year over a } 40 \text { year life. } \\
\text { Project Estimate: Considering a service life of } 20 \\
\text { years and the annual maintenance costs evaluated in } \\
\text { Figure } 3 \text { (full infiltration design): } 54,450,000+(20 \mathrm{x} \\
3,252,167) \rightarrow 64 \text { AED per } \mathrm{m}^{3} / \text { year }\end{array}$ \\
\hline 4 & $\begin{array}{l}\text { Advantages \& } \\
\text { Dis-advantages }\end{array}$ & & \\
\hline 4.1 & $\begin{array}{l}\text { Dubai, UAE - Rising } \\
\text { groundwater table elevation }\end{array}$ & $\begin{array}{l}\text { Slotted storm-water pipes at depth may be } \\
\text { utilised for groundwater table reduction } \\
\text { whilst additionally act as carrier drains. }\end{array}$ & $\begin{array}{l}\text { Without under-drain components, unlike } \\
\text { conventional drainage options (and the dual } \\
\text { requirements of the Dubai regional network) an } \\
\text { infiltration system is not capable of both controlling } \\
\text { groundwater table elevations and conveying run-off } \\
\text { (minimum } 1 \mathrm{~m} \text { level difference to be maintained } \\
\text { from sub-base formation to groundwater table for } \\
\text { full and partial infiltration designs). } \\
\text { Dubai Municipality guidance [3] requires drainage } \\
\text { design to control groundwater in areas where water } \\
\text { levels are within } 2 \mathrm{~m} \text { of the ground surface. }\end{array}$ \\
\hline 4.2 & $\begin{array}{l}\text { Pollutant control/ Water } \\
\text { quality enhancement. }\end{array}$ & $\begin{array}{l}\text { Mechanical filtration modifications will be } \\
\text { required to conventional gully and piped } \\
\text { drainage designs. }\end{array}$ & $\begin{array}{l}\text { 5\% significance level improvements in storm-water } \\
\text { quality, with permeable over conventional, } \\
\text { impermeable pavement designs. } \\
\text { Mechanical filtration performed by the component } \\
\text { layers of the permeable pavement construction; } \\
\text { chemical pollutants bound to fine sediments being } \\
\text { trapped within the upper pavement layers. }\end{array}$ \\
\hline 4.3 & Resistance to clogging & $\begin{array}{l}\text { Gully emptying is conventionally required on } \\
\text { a twice yearly basis. } \\
\text { Pipework should otherwise be designed to be } \\
\text { self-cleansing (maintaining min. } 1.0 \mathrm{~m} / \mathrm{s} \\
\text { velocity). }\end{array}$ & $\begin{array}{l}\text { Design infiltration rate through the pavement surface } \\
\text { is considered as } 10 \% \text { of initial infiltration rate, to } \\
\text { account for clogging effects over a } 20 \text { year design } \\
\text { life without maintenance. }\end{array}$ \\
\hline 4.4 & Recharging of aquifers & $\begin{array}{l}\text { Where no infiltration is permitted, no } \\
\text { recharge of groundwater is achievable. }\end{array}$ & $\begin{array}{l}\text { Ground infiltration through Systems A \& B permits } \\
\text { the recharge of aquifers and groundwater, } \\
\text { particularly of benefit to arid regions such as those } \\
\text { prevalent in the middle east }\end{array}$ \\
\hline 4.5 & Energy savings & $\begin{array}{l}\text { Multi-stage pumping requirements where } \\
\text { discharge required to large storage/ retention } \\
\text { facilities at undeveloped, suitable locations. }\end{array}$ & $\begin{array}{l}\text { Total mitigation of requirements for pumping in } \\
\text { most cases, with infiltration/ discharge close to the } \\
\text { points of entry }\end{array}$ \\
\hline
\end{tabular}




\section{PERformance Evaluation}

The effect of clogging of surface layer jointing is a significant factor and limitation on the manufacturer estimated service-life of permeable pavement structures. Globally, active maintenance, inclusive of suction sweeping of completed road surfaces, combined with coarse stone regritting of block paving joints is essential for continued hydraulic conductivity and infiltration performance of the upper pavement layers. More regular vacuum brushing using a standard road sweeper has been recommended for the project to prevent surface ponding (refer to Fig. 2; twice to three times a year). Wind-blown fine sand and debris from currently undeveloped landscaping will continue to present a problem until full scheme completion. This is a common issue across many UAE private developments, often surrounded by undeveloped, desert land for long periods and constructed in independent phases.

Infiltration performance is highly affected by grading of joint materials, where coarse particle size materials exhibit improved performance over fine-grained aggregate alternatives. Age also has a significant impact, where the top $20 \mathrm{~mm}$ of joint materials is most heavily impacted by entrainment of mineral and organic fines over time. Typical percolation values for a newly constructed permeable pavement $(4000 \mathrm{~mm} /$ hour on average) are predicted to reduce to performance levels of $10 \%$ to $25 \%$ of original capacity over the first 10 years of operation, stabilising at this point until an end of service life at +20 years (Borgwardt (2006), [12]). Less significant is the ratio of openings to impermeable block area, optimised at approximately $10 \%$. With the increased regularity of sweeping and works for rectification of clogging following construction activities specified for the project, joint material replacement in accordance with the original construction specification will be more frequently required than for a typical installation (refer to Fig. 2; 1/5 expected initially vs. $1 / 15$ conventional intervention intervals).

Structural pavement deterioration is primarily related to vehicle loadings, number of axle loadings and spacing's within the axle group. Cracking is exhibited in both rigid and flexible construction, whilst rutting and settlement principally affects flexible pavements. Construction quality has an important effect on pavement durability. Road surface irregularities as a consequence of poor workmanship in permeable CBP installations can create a "bouncing effect", combining with the increased amplitude and frequency of vehicle vertical motion to cause specific "damage locations" (see [8]). For the project, weather and subgrade conditions have additional effects on pavement durability as detailed throughout this paper, whilst pavement material quality and construction detailing were effectively controlled through dedicated construction supervision and design based on well established guidelines (Interpave UniClass L534:L217 2010; Guide to the design, construction and maintenance of concrete block permeable pavements, [5]).

\section{CONCLUSION \& RECOMMENDATIONS}

Economic downturn had significant impacts on villa and infrastructure procurement strategies, stalling contracts at variable stages of development and resulting in highly disjointed construction sequencing for the community villas and roads infrastructure. Fully integrated re-mobilisation master planning to ensure minimal construction trafficking of completed permeable road networks was unfortunately not achievable. Notably, programme co-ordination was compromised, preventing the ideal provision of a temporary running surface. Compacted subgrade and/or a capping layer, or impermeable DBM running surface over permeable subbase layers may otherwise have been provided to service completion of villa construction activities. Removal of sacrificial layers and installation of the remaining permeable pavement laying course and blocks would then proceed following villa construction completion.

The ring-road SuDS solution was well designed and executed with no noticeable flooding/ ponding areas observed under storm conditions over the past five years. Plot planning guidelines were also effectively communicated to subdevelopers for independent villa developments, ensuring containment of plot drainage within the plot limits. Utilising varying french drains, soakaways, channel drainage and alternative lattice storage measures within plots allowed for effective value engineering, through design flow consideration for the community road carriageways only.

During heavy rainfall events, ponding is observed at permeable CBP low points in a number of communities. Infiltration deterioration is clearly observed and largely attributable to variable levels of clogging of surface paving joints, combined with some amount of structural deterioration as outlined in section III of this paper, resultant from heavy construction trafficking and landscaping run-in. Surface water drainage performance however remains largely acceptable, with flood volumes after storm events substantially removed within the Dubai Municipality recommended 'clear time' of six hours. The completed roads network was subjected to the highest intensity rainfall event of the past five years, occurring on 22 November 2013, with $10.7 \mathrm{~mm}$ in 90mins. Bespoke maintenance/ restoration measures provided by the pavement manufacturer (Hanson Formpave $\AA$, see [15]) for implementation post-construction and through regular maintenance cycles are expected to restore permeability significantly.

Key project design and construction recommendations include:

1) Inclusion of secondary discharge/ overload systems for outfall storage in the event of excess rainfall intensities: The ring-road to community roads are adjoined at permeable CBP roundabouts, with flush kerbs provided at the outer perimeters to promote routing of excess flows to ring-road swales and detention features. Closer integration of community and ringroad networks could facilitate maximised usage of ring-road landscape contouring for potential outfall storage from permeable roads via a conveyance system. 
2) Future enhancements of bespoke drain inlets within the flush kerb-line or perforated pipe under-drain provisions at low points susceptible to ponding in extreme events, for subsequent conveyance past the permeable CBP system: The above retrofitting would require closer interconnection of ring-road infiltration measures and/or discharge to dislocated soakaways, rainwater harvesting detention storage features or the re-circulating golf-course irrigation lakes. Alternatively the sub-base storage reservoirs of disconnected, remotely located driveway or parking bay permeable CBP may be utilised (areas with available freeboard) for relief of unacceptable ponding depths during heavy rainfall events at affected low points.

3) Detailing enhancement of 'check dam' flow controls for slopes in excess of 5\% (1 in 20 gradient): Whilst full height restraints (FHR's) compartmentalise aggregate storage areas and use of sub-base infiltration trenches increases storage capacity at the location of low points, 'check-dam' flow controls were not utilised. Incorporation of piped interconnections between storage areas would allow for flowoptimised storage space to further mitigate localised flooding in the event that design capacity is exceeded.

4) Consideration of bespoke paving joint treatments/ joint sealant for bonding joint materials is a clear area of required development for middle-east applications, where wind-blown fine sand joint penetration is a critical concern: A fully integrated SuDS solution is clearly heavily impacted by construction detailing, planning and installation methodologies, with further research and development needed to comprehensively tailor permeable CBP for Middle East applications.

\section{REFERENCES}

[1] B Shackel "The Challenges of Concrete Block Paving as a Mature Technology', Available:

https://www.icpi.org/sites/default/files/techpapers/1021.pdf

[2] United Nations Agenda 21 - Action plan of the United Nations with regard to Sustainable Development. Available: http://en.wikipedia.org/wiki/Agenda_21

[3] Dubai Municipality Sewerage and Drainage Design Criteria (Mf/ma/drainage-Design-Cr-19-10.doc), Dubai Municipality, 1996.

[4] CIRIA susdrain - delivery of Sustainable Drainage Systems. Available http://www.susdrain.org/delivering-suds/using-suds/sudscomponents/source-control/pervious-surfaces/pervious-surfacesoverview.html

[5] Permeable Pavements, Guide to the design, construction and maintenance of concrete block permeable pavements, Interpave Uniclass L534:L217 Edition 6, January 2010.

[6] D. Brocard, E. George, L. Salem and B.S. Pradeep, 'Modelling the Dubai Sewerage and Drainage Systems,'”. Available: http://www.dhigroup.com/upload/publications/brocard.pdf

[7] Source control using constructed pervious surfaces, CIRIA C582, London, 2002.

[8] The costs of paving, Comparative initial construction and whole life cost analyses for pavements, Interpave Uniclass L534:L217, July 2006.

[9] $R$ Shahin. and W. James, 'A Laboratory Examination of Pollutants Leached from Four Different Pavements by Acid Rain. In: Advances in Modelling Management of Stormwater Impacts, "' Volume 6, Michigan, USA, CHI Publications, Thomson-Shore Inc., ISBN: 0-9697422-8-2, 1994

[10] Performance and whole life costs of best management practices and sustainable urban drainage system, UKWIR, 2005.
[11] Manual of contract documents for highway works. Volume 1 Specification for highway works. Highways Agency, May 2004.

[12] S. Borgwardt, 'Long-term In-situ Infiltration Performance of Permeable Concrete Block Pavement,"' in Proc. 8th International Conference on Concrete Block Paving, November 2006.

[13] $R$ Bettess, 'Infiltration drainage - manual of good practice', CIRIA (R156), January 1996

[14] Daywater, 'Review of the use of stormwater BMPs in Europe. Adaptive Decision Support System (ADSS) for the Integration of Stormwater Source Control into Sustainable Urban Water Management Strategies,' Middlesex University, Report 5.1 Project under EU/RTD 5th Framework Programme, August 2003.

[15] Hanson Formpave Aquaflow ${ }^{\circledR}$ permeable block paving and SUDS. Available:

http://www.heidelbergcement.com/uk/en/hanson/products/block_pavin g_and_suds/commercial_aquaflow_permeable_block_paving_and_SU DS.htm 